\title{
Rethinking the Historical Development of Caribbean Performance Culture from an Afro-Iberian Perspective
}

The Case ofJankunu

\author{
Jeroen Dewulf | ORCID: 0000-0003-4579-3086 \\ University of California, Berkeley CA, USA \\ jdewulf@berkeley.edu
}

\begin{abstract}
This article advocates for a new perspective on Caribbean performance traditions by adopting an Afro-Iberian perspective. It argues that we are able to acquire a better understanding of the historical development of some of the most enigmatic Caribbean performances, including Jankunu, by taking into consideration that many of those who built the foundations of Afro-Caribbean culture had already adopted cultural and religious elements rooted in Iberian traditions before their arrival in the Americas. A comparative analysis demonstrates a series of parallels between early witness accounts of Jankunu and Iberian calenda traditions. In order to explain this, the article points to Iberian dominance in the early-modern Atlantic and, in particular, Portuguese influences in Africa. It highlights the importance of confraternities and argues that it was in the context of African variants of these mutual-aid and burial societies that elements rooted in Iberian traditions entered Afro-Caribbean culture.
\end{abstract}

\section{Keywords}

Jankunu - Jamaica - Africa - Portugal - Catholicism

As Joseph C. Miller has argued, enslaved Africans who arrived in the Americas in the early seventeenth century came to live in intimate contact "with predecessors who had arrived in small numbers from backgrounds in slavery in 
late medieval Iberia" and "particularly those coming through Kongo channels ... must have had a useful familiarity with Portuguese Christianity and used it to find places for themselves without relying on the more 'African' aspects of their origins" (Miller 2002:61).

The familiarity of these groups with Iberian cultural traditions necessitates caution in the analysis of their cultural expressions. It is no accident that Miller has placed the term African in quotation marks. It is, in fact, questionable whether seventeenth-century Kongolese considered originally Portuguese, Catholic elements "un-African." After all, these elements had arrived in the Kongo region in the late fifteenth century and had, over time, become a natural part of the cultural and religious traditions many had grown up with. In spite of their European roots, these traditions were, thus, not necessarily perceived as different from indigenous customs. As John Thornton has argued, "a Kongo peasant living in the mid-eighteenth century might have been unaware that knowledge about some of the beings he worshiped - such as the Virgin Mary, so often invoked in times of danger or emergency—actually originated outside his country" (Thornton 2007:63).

The cultural and religious identity of these groups not only refutes essentialist definitions of the term "African," but it also questions the traditional use of the term "syncretism" as a phenomenon that only set in after Africans had arrived in the Americas. Acknowledging this requires us to look at the historical development of Afro-Caribbean festive traditions through a new lens. As Marina de Mello e Souza pointed out, even in performances in which participants use "European clothing" or celebrate "a Catholic saint," we may "discern the direct link to ... an African past that was already infused with European elements ... since the beginning of the sixteenth century" (Souza 2015:43). In Afro-Catholic Festivals in the Americas, Cécile Fromont confirmed that festive traditions rooted in African interpretations of early-modern Iberian customs could "easily be misinterpreted in the Americas as new, Creole syncretisms" (Fromont 2019:10).

Already in the 1980s, Ramiro Guerra had alerted us to this danger and had introduced the notion of doble sincretismo (double syncretism) as an alternative (Guerra 1989:41). He did so with the conviction that the selective integration of European elements in Black cultural traditions was not a phenomenon that had started in the Caribbean but, rather, was one that built on an earlier syncretic process that had begun in Iberia and Africa. Guerra's expression allows for a more nuanced and multilayered approach to the notion of syncretism; yet, as Jonathan Friedman pointed out, "all cultures have always been the product of import and a mix of elements" and "it is not the origin of its elements but the way they are synthesized that is the specificity of a culture" 
(Friedman 1997:81). The use of concepts such as "syncretic," "hybrid," or "Creole" in such terms runs the risk of confusing geographic origins with the practice of cultural integration as the defining characteristic of culture.

The importance of cultural integration demands that greater attention is paid to social factors and, in this specific case, to the question of why elements rooted in Iberian traditions were absorbed by Africans in the first place and why they became a constituent factor in the development of Afro-Caribbean performance culture. These questions bring a complex set of factors into play, including community-building, religion, protection, solidarity, power, and pride, which in an Iberian colonial context have traditionally been associated with mutual-aid and burial societies. As Francisco Bethencourt confirmed, the formation of such (con)fraternities, or brotherhoods, was "one of the principal processes of transferring European structures to other regions of the world" (Bethencourt 1998:385). Considering the importance of brotherhoods in Black cultural and religious identity formation in Iberian colonies, any discussion of Afro-Iberian influences on performance traditions outside of Latin America necessitates that specific attention is paid to the role of similar fraternal organizations.

In this article, I will apply these theoretical reflections to an analysis of Jankunu. While this enigmatic performance tradition has typically been associated with Jamaica, the island where we find the oldest references dating back to the eighteenth century, it has also been registered elsewhere in the Caribbean and even in Central America and the American South. Although it has received abundant scholarly interest, many of the questions raised by early witness accounts have remained unanswered: Why did people wear costumes made of rags, masks, ox-horns, a bullock's hide with tail, and sheep-skins? Why did they parade with a band and a flag? Why did some carry wooden swords in their hands and others models of a house or boat on their heads? Why were there kings involved in the celebration, and a little child? Why did Jankunu take place at Christmas, why did the performers come to greet their masters, and why did their performance coincide with groups of Afro-Jamaican women, called sets, who paraded through town in beautiful clothing?

I will start my analysis by identifying a number of parallels between these accounts and Iberian traditions that used to take place during a festive period known in late-medieval Iberia as the calendas, meaning the 12 days before and

1 Early sources on Jankunu include Anonymous 1828:289-94; Beckford 179o, I:390-92; Belisario 1837; Bolton 189o:222-23; Cundall 1907:65-66; Higman 1976:21-22; Lewis 1834:51-59; Long 1774, II:424-25; Phillippo 1843:93-94; Scott 1835:161-66; Warren 1885:200-3; Williams 1826:2526; and Wright 1937:240-41. 
after Christmas. Contradicting Judith Bettelheim, who claimed that "Jonkonnu performance is secular" and that "the correspondent with Christmas is merely historical," Iberian Christmas festivities form the groundwork for my interpretation (Bettelheim 1979:81).

I will then elaborate on the reasons why Africans integrated Iberian elements into their traditions. In contrast to Mary Turner, who referred to Jankunu as "circuses in which the slaves provided the whites with exotic entertainment," I will relate this tradition to self-organized mutual-aid and burial societies that provided the enslaved the necessary leeway to develop a singular cultural identity (Turner 1982:51-52). I will conclude with a reflection on the role of religion in Jankunu. Similar to Kenneth Bilby (2010), who rejected claims that Jankunu is a secular tradition, I will stress its religious nature. However, whereas Bilby associated this aspect primarily with indigenous African religious culture, I will argue that Afro-Catholic religiosity constituted, from the outset, an important component of the tradition.

Studies have shown that the foundations built by charter generations tended to have a profound influence on the development of Black cultural identities in slave societies. ${ }^{2}$ In the case of Jamaica, these foundations were laid during the island's Spanish era. Research by Carla Pestana has shown that by the time of the English invasion in 1655, "most African-descended peoples" in Jamaica "were ladinos," who "had become acculturated, especially mastering the Spanish language" (Pestana 2017:146-47). Not all enslaved and free Afro-Jamaicans accompanied the Spanish exodus to Cuba in 1655 . Some joined Spanish forces in a guerilla campaign and were later captured or surrendered voluntarily, while others fled to already existing maroon communities or formed their own. These Spanish-speaking maroons, known in British sources as "Spanish Negroes," remained in Jamaica after the Spanish surrender in May 166o (Campbell 1988:14-25; Morales Padrón 2003:155-57, 212, 257; Pestana 2017:183-214). In later decades, other Hispanicized people with African roots kept arriving on the island as a result of contraband, warfare, and piracy activities. For instance, Pablo Miguel Sierra Silva's research on the 1683 abduction of 1,500 Africandescended females from Veracruz, Mexico, by a coalition of Dutch, French, and English buccaneers revealed that most of these "Spanish-speaking, Catholic women" were taken to Saint-Domingue, while others ended up in Jamaica

2 Heywood \& Thornton 2007a:262; Mintz \& Price 1992:42; Mufwene 1996:83-134; Sensbach 2005:92; Wheat 2016:252. 
(Sierra Silva 2020: 4, 27). We should also take into consideration that some of the enslaved in Jamaica had already familiarized themselves with Portuguese cultural and religious traditions in Africa. Not surprisingly, thus, traces of Catholic/Iberian influence continued to show up among Jamaica's Black population long after the island had been conquered from the Spanish. Newspaper advertisements about runaways from the 179 os refer, for instance, to a "Negro woman with a crucifix necklace" and to another one as "speaking Portuguese" (Amussen 2007:164-67; Mullin 1992:26).

That this has importance for the development of performance traditions can be illustrated by Sloane's observation in the early eighteenth century that AfroJamaicans used to refer to Easter as "piganniny Christmas," as derived from the Portuguese pequenino, very small (Sloane 1707, I:LII). Similar Iberian linguistic influences have been recorded elsewhere. On the islands of Dominica and Trinidad, for instance, Christmas performances organized by African descendants typically involve the participation of a little donkey known as the burrokeet, as derived from the Spanish burroquito (Nicholls 2012:124). This use of Portuguese and Spanish terms shows that Iberian influence on Black cultural traditions outside of Latin America is not a chimera.

We could, in this respect, also refer to contemporary Jankunu celebrations in Belize by members of the Garifuna community-ethnically mixed AfricanIndigenous people who in the late eighteenth century were exiled to Central America from the island of St. Vincent. These festivities, known as Wanárague/ Wandragua/Wandragawa, take place on what they call Dia-Rey, as derived from the Spanish/Portuguese Dia de Reyes/Reis, Epiphany (Bilby 2010:205). They extend from Christmas over New Year to Epiphany and therefore span a festive period that corresponds to what in late medieval Iberia was known as the calendas.

The latter term derives from the Latin kalendae. In the Roman Empire, the kalends of January marked the beginning of the calendar year, which coincided with a variety of festivities involving masquerading, mockery, and crossdressing. The celebration of the kalends expanded rather than diminished once the Roman Empire adopted Christianity and, in spite of opposition by Church authorities, survived much longer into the Christian era than any other Roman festival. The Latin term continued to be used in the periphery of the ancient Roman Empire, as reflected in the Romanian Christmas carols known as colinda românească, the Spanish villancicos de calenda, and the Portuguese calendas janeiras (Bratulescu 1981; García Martín 2011:454-6o; Vasconcellos 1904, II:849-61).

As John Chasteen confirms, "during the entire first millennium of Christianity in Europe, church authorities worried occasionally about the persistence 
of pagan dance rites called (in Spanish and Portuguese) calendas" (Chasteen 2004:167). The latter, also known as quendas in Portuguese, referred to a festive period that began 12 days before and ended 12 days after Christmas, corresponding to the moment when Mary started her search for a safe place to give birth (known in Spanish as Las Posadas) until the visit of the Magi and the revelation of God incarnate as Christ on Epiphany. Epiphany festivities in Iberian culture thus marked the end of the calendas and subsequently initiated a new festive period, carnival, formerly also known as carnestolendas. ${ }^{3}$

Due to the prominent presence of a Black king, Epiphany was a day of high importance for Iberia's African-descended community, as is reflected in the dissemination of Black confraternities dedicated to Our Lady of the Kings (Vincent 2000:26). An interesting characteristic of these brotherhoods was their use of European aristocratic titles for leadership positions. The 1565 charter of the Lisbon Irmandade de Nossa Senhora do Rosário dos Homens Pretos (Brotherhood of Our Lady of the Rosary of the Black Men), for instance, called for the election of a "prince, king, duke, count, marquis, cardinal, and any other dignity" (I. Pereira 1968:23). These titles did not relate to Africans of noble birth, nor should they be misunderstood as a form of parody or role reversal. Although we know little about their precise meaning, brotherhood kings and nobles undoubtedly enjoyed great prestige within their community. It was no accident that the king, traditionally the first person to be elected, held the power to decide on even votes and had the authority to expel members (Fonseca 2016:107-11; Lahon 2001:382-85, 475, 505).

Among the highlights of the calenda season were the nightly vigil on Christmas Eve, where people celebrated the birth of Christ with prayers, veneration songs, music, and dance, as well as the procession to and from church to hear the Misa de Gal(l)o, Midnight Mass. In Portugal, it was also common for humble people to organize janeiras/janeiradas, also known as cantar os reis (singing the kings), parades, with music and dance, to wish wealthy families a merry Christmas or a happy New Year in exchange for a donation, often in the form of sobras, the leftovers of the previous evening's festive dinner. Moreover, the calendas were a time for masqueradas, performances involving masking. Among the most popular was the pastoral, a morality play about shepherds who, on their way to the infant Christ, are interrupted by Herod, Lucifer, or other enemies of Christ, requiring the intervention of the Archangel Michael and his angelic

3 Braga 1885, II:323; Moreno 1997:49; Phillips 2014:94-95; Ruiz 2012:47; Terreros y Pando 178693, I:315. 
soldiers. This play typically involved elements from Catholic nativity scenes, including sheep, donkeys, and oxen. A variant was the reisado/reiseiro/folia de reis, about the Magi following the Star of Bethlehem, who, in reference to the Massacre of the Innocents, put on masks and act like clowns to outsmart Herod and his armed soldiers, who are searching for the infant Christ. Reisados typically included the participation of a "child king" and a number of clowns, known as the locos/bobos or, if cross-dressed, locas/bobas (crazy ones), who entertained the public with antics while collecting donations. Some of them performed on stilts, a creative solution to the fact that wealthier families preferred to watch street animation from their balconies. In the context of the peninsular wars, yet another variant of the eternal struggle between good and evil forces developed, known as Moros y Cristianos/Mouros e Cristãos (Moors and Christians). In this mock war performance, inspired by Carolingian mythology, the Moors (typically dressed in red) seem to obtain victory but are eventually defeated by Christian forces (typically dressed in blue) and forced to bow down in order to be baptized.

These performances were traditionally organized by brotherhoods and started with a parade, in front of which walked a flag-bearer carrying the fraternity's banner and a marching band, who were followed by a group of soldiers escorting the king and dignitaries. Participation in these plays had a religious meaning as ex-voto, in the Catholic tradition of expressing gratitude to a saint for the fulfillment of a vow-hence the use of ribbons or streamers in reference to saints. Since saints were thought to be moody and potentially vengeful, there was a firm belief that not honoring one's vows, or only doing so halfheartedly, could have disastrous consequences, not just for oneself but also for one's relatives, friends, or community. ${ }^{4}$

According to Max Harris, "Kalends masquerading during the Christian era did, in all likelihood, exercise some influence ... on European (and even, eventually, American) carnival customs" (Harris 2006:59). This influence was not limited to carnival, however. An early reference to a Christmas celebration in the Americas influenced by calenda traditions can be found in Le Gentil de La Barbinais's report on a 1717 "nativity farce" at the Convent of St. Clare in Salvador da Bahia, Brazil. It involved "charivari songs" during which the nuns danced and jumped so wildly that it reminded the French globetrotter of an African lundu dance (Le Gentil de La Barbinais 1728, III:149-51). Oneyda Alvarenga pointed out that "it was an old custom" in Brazil "to form ranchos,"

4 Beirante 1990:14; Beirante 2011:31, 174-82; Brandão 1977:10; Chaves 1945:41-42; Harris 200o:32, 132-52; Marques 1971:224; Mauldin 1999:3-6; Oliveira 1984:207-10; Rawlings 2002:78; Ruiz 2012:38-39, 255-56; Vilar 1995:215. 
who "during the feasts of Christmas and Epiphany perform in front of the houses of wealthy people with dances and songs of praise" that were a "convergence of traditional customs, some of them ... dating back to the calendas" (Alvarenga 1982:32). We could also mention traces of the pastoral in villancicos, which, as Larissa Brewer-García explained, were "popular at Christmas on both sides of the Atlantic in the Iberian World" and had "as the principal theme ... the celebration of shepherds reacting to the news of Jesus' birth." In some villancicos de negro, Black characters, describing themselves as "confraternity members of the Christmas Star," would "sing the part of the humble shepherds who were the first to receive the evangelical message of Jesus' birth" and praise "the gifts brought from Angola by the three kings" (Brewer-García 2020:44, 48, $50)$.

Parallels between calenda traditions and Jankunu can be illustrated with reference to the Garifuna. Robert Dirk's anthropological research from the 1970s revealed that these celebrations typically start with a parade, whereby a "troupe of John Canoes on Christmas day is heralded by a flagman," who is followed "by a 'king'." The performers are all male, some wearing "male outfits" while "others don female garb" that is "embellished with numerous ribbons, sashes, bits of cloth, and paper streamers." They wear "wire mesh masks painted white and headdresses fashioned from cardboard and decorated with ribbons, plumes, and pieces of mirror." These "Antics Men" do "foolish things to annoy the king and draw laughter from onlookers." Most dancers, Dirks explains, "brandish a wooden sword, usually painted blood red" (Dirks 1979:91-2 and 1987:174). Accounts from the 1920 also refer to "dances ... performed on stilts" and to a parallel Christmas festivity involving a "horned devil" and a "pregnant woman" (Craton 1995:22).

While there are good reasons to study the Wanárague in connection to Jamaican Jankunus, the parallels with the reisado - the cross-dressed "antics men," kings, swords covered with blood, et cetera-are so overwhelming that this festive tradition could just as well be classified as a Central-American variant of the countless performances that developed out of this play in Latin America. Although the Garifuna undoubtedly celebrated the play in their own way and gave new meaning(s) to it, elements of Iberian origin are still very recognizable in its basic plot and structure. These elements cannot simply be discarded by scholars studying the Wanárague in parallel to the Jamaican Jankunu, especially if the reason for the comparison relates to a search for the latter's roots.

We could, in this respect, point to the Garifuna's use of wire mesh masks painted white which, as Bilby pointed out, also appear at Santiago Apostol celebrations of the African-descended community in Loíza, Puerto Rico (Bilby 
2010:215). According to Ricardo E. Alegría, the latter developed out of the play Moors \& Christians, as a mock fight between one group dressed as Moors and another using wire masks to represent Spanish caballeros. While the Moors have meanwhile disappeared from the scene, they survive in today's vejigantes, men wearing horned masks, who, according to Alegría, "represent evil, the devil, the Moors whom the Santiago Apostol and the caballeros combat" (Alegría 1956:130). Similar to what occurs in the Wanárague, the locos and (crossdressed) locas entertain the audience with antics, while collecting money for the organizing fraternity. In his earliest studies, Alegría still argued that St. James the Apostle was a representation of the Yoruba deity Shango. After learning about similar mock-war performances in honor of St. James in Kongo, however, he revised his opinion. ${ }^{5}$ Today, similar to Harris (2001), Alegría (2006/o7) argues that this performance should be understood in connection to the crucial rule of St. James in the foundation story of the Kingdom of Kongo.

Considering these shared Afro-Iberian roots, it should not come as a surprise that virtually the same masks of screen wire appear in Luso-African theater performances on the islands of São Tomé and Príncipe. Remarkably, the custom of sprinkling rum on the graves of the ancestors before starting the performance, as observed by Bilby at Jankunus in rural Jamaica, is also common practice on these African Atlantic islands (Bilby 2010:192). In São Tomé and Príncipe, this custom has been associated with ex-votos and devotional practices to the souls of the deceased. ${ }^{6}$

That Iberian traditions from the calenda period also influenced Black festive customs on Caribbean islands once ruled by Protestant nations can be illustrated with reference to Bonaire. One of the cultural highlights of this former Dutch colony takes place on New Year's Day and Epiphany and is known in Papiamentu as the maskerada. Early witness accounts refer to people representing kings, identified by their crowns; soldiers with swords; and men dressed as donkeys and oxen. Participants parade with their flags and bands, are covered in paper streamers, and wear a similar type of wire mesh mask as the ones mentioned above. In accordance with Iberian tradition, the performance used

5 For a visual representation, see https://www.youtube.com/watch?v=0oU43HobJaM (accessed October 7, 2020). For more on performances in honor of St. James the Greater in Kongo, see Dewulf (2017:21-46), Fromont (2014:21-26), and Thornton (1998:30-35). For a parallel to Haiti, see Cosentino (1995:243-63).

6 Ambrósio 1992:341-44; Dumas 2011:152-53, 246-47, 273; Reis 1969:53-121; Valverde 1998:45, 74. For a visual representation, see https://www.youtube.com/watch?v=ynMAHfhoUn8 (accessed October 7, 2020). 
to require a visit, in parade and with accompanying music, to the presbytery, where members were given a blessing by a Catholic priest before starting their festivities. $^{7}$

If we now shift our focus to Jamaica, we find indications that, there too, African-descended people found inspiration in Iberian calenda traditions. Influences from the pastoral and reisado, for instance, can be found in Hurston's report, from the 1930s, about an Afro-Jamaican Christmas celebration that involved a "shepherd ... followed by the Sword Boy, carrying a wooden sword," after whom came "the Symbol Boy with a cross, chanting." This performance was explained to her by a participant as a search of "three wise men [who] see the star but they can't fin Him because He is hid in cave" and "when they can't fin Him after six months, they make a magic ceremony and the angel come tell Joseph the men wanted to see Him" (Hurston [1938] 1990:4).

That such performances were not a recent phenomenon can be illustrated with reference to James Phillippo. In his 1843 study of Jamaica, the Baptist missionary explained that it was common "on public holidays, particularly those of Christmas" that "each of the African tribes upon the different estates formed itself into a distinct party" with "its King or Queen." These groups then "paraded or gambolled in their respective neighborhoods, dancing to the rude music." In the towns, "such processions were preceded by a tall athletic man, attired in ... grotesque habiliments, in addition to which he wore a most hideous headdress surmounted by a pair of ox-horns." Phillippo specified that this man was known as "John Connu" and that he "bore in his hand a large wooden sword." Accompanied by "musicians," he and his followers "paraded the streets, and exhibited themselves in private houses." Phillippo also mentioned that, on New Year's Day, "sets of young women, or dancing girls, often elegantly dressed, and distinguished as reds and blues ... went from house to house ... and danced for voluntary gifts," while wearing a dress "furnished in many cases by her owner." Whereas these passages from Phillippo's study are well known, it is often ignored that he returned to the topic later in his book by explaining that Afro-Jamaicans had constituted their own Afro-Christian fraternities and that "at Christmas it was customary for them and their disciples to go in groups into the woods, or, if there were any in the neighbourhood, among the sheep, over which they pretended to watch, in imitation of the shepherds, to whom the angels announced the birth of the Redeemer" (Phillippo 1843:93$94,103)$.

7 Brenneker 1969-75, I:134 and 1986:41; Van Panhuys 1933/34:318-20; Rosalia 1997:123. In recent celebrations, the swords have disappeared. For a visual representation, see https://www .youtube.com/watch?v=sdGgfGBNYIA (accessed October 7, 2020). 
While this practice, which may have been an early form of Myal, has hitherto not been associated with Jankunu, the Iberian calenda could serve as the missing link. It is, in this respect, interesting to note that the (only) two songs labeled as "African music" in the late eighteenth-century anonymous manuscript Characteristic Traits of the Creolian \& African Negroes in Jamaica are "the Myal" and "the Calemba" (Higman 1976:19; Leigh 2019:463-64).

Interpreting Jankunu from the perspective of calenda performances clarifies much of the scenery, from the singing and dancing for one's master at the beginning of the new year in the tradition of the janeiras; the dressing up like sheep and oxen as in pastoral plays; and references to "kings" or a "masquerader, carrying a wooden sword" and "a little child ... supposed to be a king, who stabbed all the rest" in the tradition of reisados (Long 1774, II:424; Scott 1835:162; Cundall 1907:66). These parallels are even stronger in a variant of Jankunu known as "Masquerade" or "Fancy Dress," which challenges Bettelheim's interpretation of "representations of an early modern Europe" in scenes of people parading as "kings, queens, bishops, and courtiers" as a reflection of "British influence" on Afro-Jamaican culture (Bettelheim 1979:85; 1988:50).

\section{$2 \quad$ Ships and Houses}

Iberian traditions could also explain the origins of yet another signature characteristic of Jankunu: that of parading and dancing while carrying a model of a ship or house on one's head. The earliest reference to this custom dates to the late eighteenth century, when the anonymous author of Characteristic Traits mentioned people carrying on their heads "a representation of an edifice," while being "attended thro' the town by a great number of Negroes, beating old canisters, or pieces of metal, singing 'ay, ay, John Canoe'” (Higman 1976:21-22). In Belisario's Sketches, we find an illustration of the "John Canoe fraternity," with a member wearing on his head a "house-boat" that was "usually constructed of pasteboard and colored papers" and "highly ornamented with heads, tinsel, spangles, pieces of looking-glass" (Belisario 1837:n.p.). The custom has also been observed in Bermuda, where Bolton reported on "an ancient African rite ... held on Christmas Eve," when "groups of men [go] from house to house singing, dancing, and playing on rude musical instruments ... bearing on their heads ... imitations of houses and ships, both lighted by candles" (Bolton 1890:222-23). A similar tradition was observed in the early twentieth-century Bahamas, where Robert A. Curry witnessed "on Christmas Day and New Year's morning" a parade on the streets of Nassau known as "Junkanoos" with "masked participants" wearing "a structure, often in the shape of a ship covered with 
shredded paper, on their heads," which some supposed "to have a Spanish connotation," but the author believed to be the "survival of an African practice" (Curry [1928] 1978:67).

This custom of carrying boat models during festive parades is not unique to Jankunu. It is also a customary practice in the Bonaire maskerada tradition. Elsewhere, Afro-Caribbean Christmas parades used to involve not just models but full-size ships. In 1893, for instance, the St. Croix Avis spoke about festivities on the Virgin Islands that included "masqueraders" pushing "a model ship of considerable size drawn through the streets" with a "numerous crew" (Nicholls 2012:92). In Barbados, similar performances involving mock naval battles came to be known under the name Landship. ${ }^{8}$

It should be noted that much older references to Black fraternities performing naval battles have been found in Latin America, often in allusion to the 1571 Battle of Lepanto and the alleged intervention of Our Lady of the Rosary in support of the Holy League. ${ }^{9}$ Just as common as the enacting of naval battles was the Iberian custom of carrying ex-votos to the Virgin on one's head during processions, including models of ships or houses. To this day, the carrying of a ship or house model on one's head as ex-voto to the Virgin is a signature characteristic of the Círio de Nazaré, an annual procession in honor of Our Lady that on the second Sunday of October brings up to two million pilgrims to the city of Belém, in Brazil (Torres 2014:82-83). The local museum Memória de Nazaré, where ex-votos of the pilgrims are exposed, contains dozens of such ship and house models. ${ }^{10}$ This custom is believed to derive from late medieval devotional practices of fishermen in the Portuguese town of Nazaré. In 1628, for instance, Manuel de Brito Alão wrote that it was common for survivors of shipwrecks to carry pieces of a sunken ship as ex-votos to the "house" of Our Lady of Nazaré in processions that involved "dances, music, guitars, tambourines, and frame drums," as well as "mockeries, mock fights, and masquerades" (Alão 2001:71, 119, 127).

The parading with ship models is also a characteristic of festive traditions in parts of West Africa with a historically strong Portuguese influence. This should not be surprising considering that Luso-African communities in the region typically engaged in shipping activities; hence their name grumetes (cabin

8 Abrahams 1967:478; Handler \& Frisbie 1972:38; Meredith 2015:89. For a visual representation, see https://www.youtube.com/watch?v=t47-1qo2dbM (accessed October 7, 2020).

9 Alvarenga 1982:61-63; Borges 2005:189-9o; Cascudo 1965:94; Dawson 2019:42-58; Harris 2000:3; Lima 1962:198-202; Liscano 1990:244-47.

10 For a visual representation, see https://www.youtube.com/watch?v=_nsXD8ERB7Y (accessed October 7, 2020). 
boys) (Brooks 2003:52-54). A distinctive feature of grumete culture is folgar (to play), the celebration of Catholic holidays with African interpretations of Portuguese festive traditions (Brooks 2003:216; Havik 2004:134). As early as the 1560s, there are references to the performance of a Portuguese auto sacramental (Catholic theater) in Buguendo (formerly known as São Domingos), in present-day Guinea-Bissau (Hair 1978:34). Early references to Portuguese festive traditions adopted by Africans can also be found in the Cape Verdean island of Santiago, where the 1604 Corpus Christi celebration involved "dances, revelry, mock war fights, St. James on his horse, a dragon, trumpets, and shawms" or in the Sierra Leone peninsula town of Porto do Salvador, where Easter was celebrated in 1610 with a grandiose procession that included "all the instruments, musicians, and singers ... one could find in that part of the world" (Barcellos 1899-1913, I:119, 173; Brásio 1958-79, IV:444-45).

Variants of these Afro-Iberian performance traditions live on in the context of mutual-aid and burial associations known as tabankas in Cape Verde and manjuandadis in Guinea-Bissau (Barreto 1938:186; Havik 2004:133-34; Kohl 2018:50, 131-62). These societies are typically led by an elected "king" and "queen," who have a "court" including a councilor, judge, jester, court ladies, soldiers, executioners (identifiable by their horns), and, remarkably, catibos (captives/slaves). Just like in Jamaican Jankunu performances, they typically announce the birth of Christ by blowing a conch shell and celebrate with parades that include banners, bands, and people carrying models of Portuguese caravels." In Guinea-Bissau, Christoph Kohl even observed a parade with entire floats in the form of a ship, carrying "seamen" singing "old Portuguese naval songs" (Kohl 2018:168-69).

As Robert W. Nicholls has demonstrated, several Christmas and New Year's "masquerading" traditions exist in Elmina and other coastal cities in West Africa, with performers using wire-mesh and papier-mâché masks similar to those in Jankunu (Nicholls 2012:243-45). While Nicholls assumed that these parallels are the result of a cross-fertilization process that ignited when AfroCaribbean soldiers serving in West-Indian colonial regiments were sent to West Africa in the nineteenth century, the historically strong Portuguese influence in the region offers an alternative explanation. Elmina has, after all, a Portuguese history that started in the fifteenth century. In his report about the Gold Coast from 16o2, the Dutch merchant Pieter de Marees observed that locals who "live with the Portuguese can tell a lot about God and his commandments ... the

11 Kohl 2018:138-39; Meintel 1984:144-45; Monteiro 1948-49:14-26; D. Pereira 2005:352; Trajano Filho 2009:37-73. For a visual representation, see https://www.youtube.com/watch ?v=znOPRL7IQ2 $\mathrm{Y}($ accessed October $7,2 \mathrm{O2O})$. 
birth of Christ, the Last Supper, his bitter passion, death, and resurrection, and other points related to our Christian religion" and that certain festivities in the region were known as "costuums," as derived from the Portuguese word costumes (traditions/habits) (De Marees [1602] 1912:76-77, 174).

Despite the fact that no Catholic priests had operated in the region since the Dutch conquest of Elmina in 1637, a late nineteenth-century Catholic mission, led by Moreau and Murat, observed that locals still had "old worn statues" from "Portuguese times" in their houses. The missionaries also noted that in Elmina a type of confraternity existed, called the "Santa Mariafo," whose members possessed a statue of the Virgin Mary and, every Friday, went about the village dressed in long, white gowns carrying candles and chanting the Portuguese words "Santa Maria” (Obeng 1996:104-7; Wiltgen 1956:143-44).

\section{$3 \quad$ John Conny}

The Portuguese influence in West Africa is also reflected in Long's etymological interpretation of the term Jankunu in his History of Jamaica with reference to "John Conny, a celebrated cabocero at Tres Puntas, in Axim" (Long 1774, II:424). The Portuguese presence in Axim dates back to the early sixteenth century and lasted until the Dutch conquest of Fort St. Anthony in 1642-hence the origin of the term caboceer (or "cabocero"), as derived from the Portuguese cabeceiro, headman. It is interesting to observe that Long assumed "John Conny" to be merely a name, without noticing a religious dimension.

In fact, the eighteenth-century English merchant Nathaniel Uring explained that the Akan-speaking population living around Elmina Castle-located some 75 miles from Axim - "have a notion of God," whom "they call John Company" (Dewar [1726] 1928:109). The oldest known reference to this supreme being comes from De Marees, who spelled the name as "Iuan goemain" and considered the existence of a term for a benevolent creator in the Akan language as proof that Africans "knew very well that Our Lord lives, above, in Heaven" (De Marees [16o2] 1912:75). The term appeared as Jan Commè and Jan Compon in Müller's seventeenth-century report on the Gold Coast with the meaning of "God, the Creator of Heaven and Earth." It was a universal superior being, he explained, and the term was also used in reference to the "God of the White People" (Müller [1672] 1968:43). In Eighteen Years on the Gold Coast of Africa, Brodie Cruickshank even speculated that Akan speakers had created the term as a result of their interaction with the Portuguese, "whose acknowledgment of one God must soon have become universally known" (Cruikshank 1853:126). In any case, it was this term, spelled as Jan Cómpon, that Jacobus Capitein, a 
Dutch Reformed Minister of African birth, used in reference to God for his 1745 translation of the Lord's Prayer, Ten Commandments, and Apostles' Creed into the Akan dialect Fante (Eekhof 1917:61; Oudschans Dentz 1920).

That the term crossed the Atlantic is shown by the Moravian missionary Christian Oldendorp, who learned in the 176os from enslaved Africans in the Danish Virgin Islands that "the general term used by the Amina [that is, the Akan-speaking people from the region of Elmina] to name God is Jankombun" (Oldendorp 2000, I:386). Jan Jacob Hartsinck, too, spoke about "a God named Jan Compaan" in his eighteenth-century report on the Guianas (Hartsinck 1770, II:902). The term also shows up in Edwards's late eighteenth-century account of Jamaica, as "Accompong," a "Supreme Being, the God of the Heavens, and the Creator of the Universe."12 Spelled today as Nyankompong or Nyankopon, this superior being is, according to Obeng, "always giv[en] the first place in all Asante rituals" (Obeng 1996:6o).

\section{Fanals}

The cross-fertilization of indigenous African and Portuguese elements in coastal towns along the west coast of Africa also explains the origin of the Fana(a)l tradition, the Upper Guinean nightly lantern parades featuring elaborate boat or house constructs (Havik 2004:194; Kohl 2018:185). Bettelheim was the first to trace this tradition to Jankunu, after observing how, in Haiti, "a small tissue-paper frame house ... a child's toy called fanal, was carried around during the Christmas celebrations" (Bettelheim 1979:98; 1985:96). Considering that Fanal parades also take place in the context of Muslim festivities at the end of Ramadan, she hypothesized that this Jankunu custom might be either a convergence of Islamic and indigenous African ceremonies that were transferred to the Caribbean, or that this custom had traveled from Jamaica to Senegambia.

The problem with Bettelheim's interpretation is that references to Fanals in the context of Ramadan festivities only appear in relatively recent sources. In contrast, Reade's 1864 description of the "Feast of the Lanterns" in Senegal noted that the parade "descended to the Gambia, and even to the Casemanche." It reveals that the "crowd of Blacks" that was "carrying the model of a ship, made of paper, and illuminated within," did so while singing "Christmas carols" about

12 Edwards 1798:157. Accompong is also the name of a historical Maroon village in Jamaica; see Dunham 1946. 
the "shepherds" and the "king of Israel" (Reade 1864:318). In Les peuplades de la Sénégambie, Laurent-Jean-Baptiste Bérenger-Féraud left no doubt either about the tradition's Christian roots when explaining that the "feast of the lanterns" in Gorée and Saint-Louis took place "on Christmas Eve ... before and after the Midnight Mass" and included the custom of stopping at certain houses to "sing praise songs" in "exchange for a gift" (Bérenger-Féraud 1879:24).

All these places share a history of Portuguese influence, starting in the fifteenth century, which makes it credible to assume that this nightly parading tradition developed out of an Iberian, Catholic custom. The carrying of a farol (lantern) during the nine-day Christmas novena processions leading up to the Midnight Mass is, in fact, an ancient Iberian tradition. Bettelheim herself recognized that such Christmas processions were a common phenomenon in colonial Cuba (Bettelheim 1985:96). As early as the 166os, we find written evidence of this in Africa, when the Franciscan Andre de Faro celebrated the feast of the Purification of Our Lady with a nightly lantern procession during his mission up the Little Scarcies River in Sierra Leone (Hair 1982:56).

In a 2017 interview, the Senegalese historian Diallo made it clear that the Fanal tradition has Luso-African roots. She traced it back to the female African partners of Portuguese or Luso-African settlers, known as senoras or nharas (from the Portuguese senhoras, ladies), who on Christmas Eve used to process to and from the Midnight Mass wearing their finest luxuries, while chamberlains illuminated them with torches. ${ }^{13}$ It is not hard to imagine that similar traditions developed in other coastal areas with a historically strong Portuguese influence. Significantly, De Marees observed that the Portuguese in West Africa maintained their female African partners "in grand style and with splendid clothes" and that the latter "always dress more ostentatiously than indigenous women ... and wear more jewelry" (De Marees [1602] 1912:225). We could also point to the region of Warri, in the Niger Delta, where John Adams observed how, in the late eighteenth century, the local ruler still dressed "in the European style," with clothes "of Portuguese fabric" that "at a former period [had] been worn by some noble peer or knight." When entering the royal palace, he found "several emblems of the Catholic religion, consisting of crucifixes, mutilated saints, [and] a large wooden cross" and, upon inquiring about their origin, was told that "several Black Portuguese missionaries had been at Warré, many years since" (Adams 1970:36-37). When visiting Warri in 1820, the British naval officer John King witnessed how the local population still organized a "large

13 Testimony by Diallo, see https://www.youtube.com/watch?v=m6xw6fNlDVo (accessed October 7,2020 ). 
Christmas procession from the city to a small village, with people carrying crucifixes and some other symbols of Christianity" (King 1822:318).

This custom could explain the tradition among Africa-descended females in Jamaica to parade in splendid dress on Christmas Eve. In 1987, Dirks had already noted that the Jamaican sets "resemble the female cofradias [confraternities] of Old Castile, which celebrated fiestas in a somewhat similar fashion" and suggested that the "sets and the related Societies of the Flowers" could either "have been handed down directly from the days of the Spanish rule" or "carried over from Hispanicized African ports" (Dirks 1987:181).

\section{Stars and Roses}

Considering these parallels to Afro-Iberian traditions, a different interpretation of the star symbol over a crescent moon on Belisario's 1837 depiction of a Jankunu performer could be suggested. Rather than an Islamic symbol that served to honor the (Muslim) Mandé community in Jamaica, as suggested by Robert Thompson, it could be understood as a reference to Stella Maris, Our Lady, Star of the Sea (Thompson 2007:99) In Catholic iconography, the moon reflecting the light of the sun represents how Mary shines in the light of Christ. Significantly, when Aniba, the prince of Assinie (in the Ivory Coast), decided to establish a Catholic Order of Knights in 1701 during his exile in France, he named it Our Lady, Star of the Sea, and chose a silver star as his badge (Roussier 1935:Xx).

This interpretation strengthens Barbaro Martinez-Ruiz's theory that the abundance of roses in the iconography of Belisario's Jankunu drawings "signify the Virgin Mary" (Martinez-Ruiz 2007:109). This interpretation also corresponds to the results of research by Sue Peabody (2002) and Yvan Debbasch (1959) into the history of Black mutual-aid and burial societies in Martinique. While the earliest such societies — dating back to the seventeenth centuryhad been confraternities dedicated to Our Lady, later variants typically adopted the name of a flower. We could also point to the island of St. Lucia, where, to this day, mutual-aid societies use the same color designations as the Jamaican sets—red for the "Roses" and blue for the "Marguerites" — and are known for their parades—-with kings, queens, and their respective courts—on the feast day of their respective Catholic patron saint. ${ }^{14}$

14 Breen 1844:192; Crowley 1958:546. For a visual representation, see https://www.youtube .com/watch?v=qFsdpJVsKiQ. Also note the parallels to Fanal in St. Lucia's lantern competitions: https://www.youtube.com/watch?v=D $3 \mathrm{~K}_{4} \mathrm{NOlHhNQ}$ (both accessed October 7 , 2020). 
Based on these many parallels, Richard Burton's Afrocentric theory that Jankunu is "the most ancient and most enduring non-European cultural form in the Caribbean," which "until the late eighteenth century ... developed without significant interference from European influence," is no longer tenable (1997:69). There can be no doubt that Iberian festive traditions are an important part of the multiplicity of cultural influences that formed Jankunu.

This also applies to the religious dimension of the tradition. As Bilby (2010) has argued, it would be wrong to understand Jankunu as a purely secular festive tradition. Its religious dimension, however, should not be reduced to indigenous African religiosity. That Afro-Catholic religiosity represents an equally important constituting element becomes clear if we return to Phillippo. The Baptist missionary traced the above-described Afro-Jamaican Christmas traditions back to North-American Blacks, who arrived in Jamaica in the immediate aftermath of the American Revolution and became "teachers and preachers." Under their influence, Phillippo claimed, Afro-Jamaicans developed "fraternities" that clandestinely organized missionary activities by sending out disciples, who traveled "by night to avoid apprehension" and then "communicated their instructions from house to house" (Philippo 1843:103-4).

It is true that Christianized African Americans such as Moses Baker and George Liele, who ended up in Jamaica during or immediately after the American War of Independence, led the foundation of the island's "Native Baptism" and influenced the development of Mayal (Schuler 1979:65-79; Turner 1982:57-59). However, a closer look at what Phillippo labeled as the "extravagant puerilities" of these fraternities reveals that their rituals included a number of elements that were undeniably of Catholic origin. Phillippo explained, for instance, that "when any of the fraternity were confined to their beds by sickness, the minister, or father, as he was usually called, anointed them with oil in imitation of the anointing of the Saviour by Mary Magdalene, before his crucifixion." The usual method of its application was "by pouring it into the palm of the hand, and rubbing it on the head of the patient; the tata, or father, singing some ditty during the operation, being joined in loud chorus by all who assembled to witness the ceremony." Phillippo specified that "these infatuated men professed a firm belief in purgatory, and, like the Romish priests, pretended an acquaintance with the destinies of the deceased." It is doubtful that Protestants from North America would have introduced the administration of the viaticum and the belief in purgatory in Jamaica. In fact, with regard to the earliest enslaved Africans on the island, Phillippo himself recognized that "some of them were Papist" (Philippo 1843:102-4). 
Phillippo's reference to their use of the Kikongo term tata (father) points toward the Kongo kingdom, where the Portuguese influence was particularly strong. That he did so in connection to fraternities is all the more intriguing considering that mutual-aid and burial societies modeled upon Iberian brotherhoods enjoyed great popularity in Kongo. A 1595 report from the Kongolese ambassador in Lisbon reveals that no less than six confraternities existed in the kingdom's capital São Salvador-those of Our Lady of the Rosary, the Holy Sacrament, Saint Mary, the Immaculate Conception, the Holy Spirit, and St. Anthony - whose members gathered daily to celebrate "Masses for the souls of the dead people" (Brásio 1952-71, III:500-4). Membership was initially the privilege of the kingdom's elite and, therefore, highly prestigious. Those admitted to a confraternity enjoyed royal protection and could in theory not be sold into slavery (Brásio 1952-71, v:6o5-14; Fromont 2014:202-6; Thornton 1984:147-67).

Starting in the early seventeenth century, King Álvaro II and his successors stimulated the creation of confraternities all over Kongo (Brásio 1952-71, v:648o, 524-32, 6o5-14; Heywood \& Thornton 20o7b:213; Rowe 2019:94). According to the Jesuit António Franco, people who joined a confraternity were expected to proselytize by taking an oath that they would "teach the Christian doctrine to uncultured and ignorant men" (Franco 1726:249, 253-56). Capuchin missionaries who arrived in Kongo by the mid-seventeenth century further contributed to the dissemination of sodalities (Franco 1726:250-53; Anguiano 1950-57, I:109-15, 349; Thornton 1984:163-64). The importance of confraternities to the Capuchin's missionary strategy is apparent in the case of Joris van Geel, who carried prewritten documents with the text "Rules of the brotherhood of ..., founded at the Church of ..." with him when he started his mission, or in Antonio de Teruel's report that he had "established schools for the education of children and several confraternities" in Mbata that were "modeled upon those in São Salvador" (Hildebrand 1940:251-54; Anguiano 1950-57, I:205).

Brotherhoods functioned as gateways through which Africans came to adopt Iberian traditions. For instance, the Capuchin Bernardo da Gallo reported in 1710 that there were four confraternities in Mbamba (those of The Holy Trinity, Our Lady of Carmel, St. Francis, and St. Anthony), whose members organized processions for which they made "a short white vest, in the manner of the Portuguese" (Jadin 1961:454-59). This decision by locals to make opas reveals how familiar they were with Portuguese fraternal traditions. We could also mention the 1620 celebrations in Luanda following the canonization of the Jesuit Francis Xavier. They involved a procession with "three giants ... followed by creoles from São Tomé, who performed their dances ... and amongst them was their king." Then the city's brotherhoods followed: "The confraternity of St. Lucia, of the Holy Mary Magdalene, of the Holy Body (Corposant), of St. Joseph, of 
the Souls of Purgatory, of St. Anthony, of Our Lady of the Rosary, of Our Lady of the Conception, and of the Most Holy Sacrament, all with their respective pennants." Then one would see a float with a ship "that represented how the saint traveled to India" and behind the ship, "one could see a swordfight that was as well performed as the best one can see in Portugal." The following day, a play was performed "whereby the Kingdom of Kongo welcomed the saint." On the eighth and final day of the celebrations, a mock battle between Christians and pagans was organized, "which involved a great spectacle of war" (Felner 1933:531-43).

It is important, however, to stress that Africans who embraced Iberian performance traditions adapted them to their own norms and values. For this reason, the Portuguese who arrived in Africa in later centuries often reacted with horror when seeing such performances. To the eighteenth-century colonial administrator João Vieira de Andrade, for instance, performance rituals "claimed to be Catholic" by the population of the island of Santiago were nothing but "errors against the Catholic Church" and "scandalous abuses, crimes, and transgressions." Andrade wrote this comment after witnessing the parade of a local fraternity and specified that "in all neighborhoods of the island women and men are elected to serve as kings and queens, who then every Sunday and holiday stage parades with their drums and flutes in order to collect money." In 1764, another Portuguese administrator, João Gomes Ferreira, complained bitterly about the "scandalous abuses, crimes, and transgressions by the so-called 'kingdoms' or Rosary confraternities," who "falsely pretended" that their rituals occurred "out of devotion to the saints" (D. Pereira 2005:337-41).

The parallels with the above-noted custom of king and queen elections in Jamaica, as described by Phillippo, are striking. That these "royals" were effectively elected is confirmed by the anonymous author of Marly, who explicitly stated that those who organized Christmas parades in Jamaica, with their flags and bands, also honored their "elected king and ... chosen queen" (Anonymous 1828:289). We could, in this respect, also point to the Virgin Islands, where Thurlow Weed observed in 1845 that "the Holidays of the slaves commence with Christmas," when "the slaves on each estate elect their Queen and Princess, with their King and Prince, whose authority is supreme," and whose "first privilege (or duty as they esteem it) ... on Christmas day and New Year's day is to pay their respects, in a body, to their master, before whom they dance for an hour or more, paying tribute ... after which they ... receive presents" (Weed 1866:34547).

It was also on the Virgin Islands that Oldendorp about a century earlier observed that most of the enslaved Africans with roots in Kongo were "Catholics and know something of the Christian faith. They call God sambiampungo 
[Nzambi a Mpungu] and call on Mary." He also noted that "among Blacks who came from Portuguese countries ... particularly those from Kongo," it was common to perform "a kind of baptism" not only for members of their own nation but also for "those bozals [newly arrived, unbaptized Africans] who desire this." Before the latter's baptism could take place, however, "an adult bozal had to receive five to six lashes from the baptizer, for the sins he had committed in Africa." Oldendorp clarified that converted bozals "receive someone who assumes the role of father or mother for them" and that, once admitted to the Afro-Catholic community, "there is a Negro celebration" and baptismal fathers and mothers "adopt those whom they have baptized as their children and look after them as best they can, in particular, when they pass away, because then they provide them with a coffin and burial clothing" (Oldendorp 2000, I:445$48,647,741-43$ and II:2, 758).

The fact that Afro-Catholic Kongolese catechists catered to the needs of newly arrived Africans and organized baptisms and funerals suggests that they operated in the context of mutual-aid and burial societies modeled upon Iberian brotherhoods and, as Maureen Warner-Lewis suggested, used rituals that "may have derived from practices within the Catholic fraternity in Koongo [sic]" (Warner-Lewis2003:186).Jon Sensbach too noted parallels between these Afro-Catholic Kongolese societies in the Virgin Islands and "Black confraternities" in Latin America (Sensbach 2005:92-93).

What becomes clear from the above-quoted sources is that enslaved Africans who were familiar with Iberian practices used this knowledge to lay the foundation for a number of social customs, most notably mutual-aid and burial societies, that were to have a profound influence on the development of AfroCaribbean identity. In this respect, the argument by Jorge Cañizares-Esguerra, Matt Childs, and James Sidbury that "approved institutional structures authorized by the Catholic Church were not always necessary for Africans and their descendants to build fraternal structures" could be extended beyond Latin America and applied to the broader Caribbean (Cañizares-Esguerra, Childs \& Sidbury 2013:9).

The assumption that enslaved people originating from parts of Africa with a historically strong Portuguese influence built, on their own initiative, fraternities in the Americas provides a credible explanation for the presence of Iberian elements in Afro-Caribbean performance traditions. It also explains why we find recurrent references to fraternities in studies on these performances; research by Frank Collymore (1957:51) on the Landship festivities in Barbados, for instance, revealed that these performances were typically associated with a "friendly society," while Bilby's research on Jankunu in the Bahamas showed that they were associated with "burial societies," one of the most prominent of which was known as "Congo No. 2" (Bilby 2010:201). 
Acknowledging the important role of fraternities implies a need for greater caution in the analysis of Christian elements in Afro-Caribbean culture. All too often, scholars have fallen into the trap of explaining such elements as a smokescreen to safeguard indigenous African rituals/spirituality against forceful Christianization. Such an assumption wrongfully reduces Christianity to a force of colonial oppression and ignores the fact that large numbers of enslaved people with roots in parts of Africa with a historically strong Portuguese influence-Kongo in particular-proudly identified as Christian and, as Souza suggested, may even have perceived Christianity as "a link to their native Africa" (Souza 2005:83). We should not forget that Christianity has a centuries-old African history - the ruler of Kongo converted to Christianity before Columbus started his first voyage to America-and that the dissemination of Christianity in early-modern Africa was not the result of successful European missionary work but rather of indigenous proselytizing initiatives at a time when the mainland was still firmly in the hands of Africans. As Annette Laing rightly argues, "it is hardly likely" that enslaved Africans who had been "raised in the Kingdom of Kongo ... where Christian ideas formed part of an inclusive and diverse package of spiritual beliefs and practices" would have "considered Christianity as part of their oppression in America" (Laing 2002:217).

In this respect, Dianne Stewart's research into the presence of Catholic saints in Orisa or Shango communities on the island of Trinidad is revealing. Stewart convincingly argues that these saints did not, as was long assumed, serve as a smokescreen behind which West-African devotees secretly worshipped Yoruba saints, but, rather, that these devotees built on earlier foundations, or "antecedents," introduced by Afro-Catholics. They did so by voluntarily integrating some Catholic elements into their Yoruba rituals, which leads Stewart to conclude that "Afro-Catholics provided the ritual architecture that allowed Yoruba sacred traditions the necessary institutional space to manifest and blossom into a nationally recognized religion" (Stewart 2019:153).

Jankunu, too, could be interpreted from the perspective of an Afro-Iberian tradition to which new, indigenously African, elements were added in Jamaica when, as Long observed, "in the year 1769 ... several new masks appeared; the Ebos, the Papaws, \&cc. having their respective Connus" (Long 1774, II:425). What this suggests is that, rather than rejecting them, the Ebo, Papa, and other newcomers built on Afro-Iberian foundations and enriched those with their own cultural traditions. 
This interpretation not only provides a credible explanation for the remarkable parallels between Jankunu and Iberian calenda performances, but it also calls for further research into the early history of the Haitian Rara, the Trinidadian Kalinda, the Louisianan Mardi Gras Indians, and other Caribbean festive traditions with similar characteristics. It is, in fact, tempting to interpret these communalities as an indication that rituals associated with Afro-Iberian mutual-aid and burial societies influenced a much broader range of Caribbean festive traditions.

\section{References}

Abrahams, Roger D., 1967. The Shaping of Folklore Traditions in the British West Indies. Journal of Inter-American Studies 9(3):456-80.

Adams, John, 1970. Sketches Taken During Ten Voyages to Africa, Between the Years 1786 and 180o. New York: Johnson Reprint Corp.

Alão, Manuel de Brito, 20o1. Antiguidade da sagrada imagem de Nossa Senhora de Nazaré, ed. Pedro Penteado. Lisbon: Colibri.

Alegría, Ricardo E., 1956. The Fiesta of Santiago Apostol (St. James the Apostle) in Loíza, Puerto Rico. The Journal of American Folklore 69(272):123-34.

Alegría, Ricardo E., 2006/o7. Loíza. Sargasso 2:xvii-xxiii.

Alvarenga, Oneyda, 1982. Música popular brasileira. São Paulo: Duas Cidades.

Ambrósio, António, 1992. O Danço Congo de São Tomé e as suas origens. Leba 7:34172 .

Amussen, Susan Dwyer, 2007. Caribbean Exchanges: Slavery and the Transformation of English Society, 1640-1700. Chapel Hill: University of North Carolina Press.

Anguiano, Mateo de, 1950-57. Misiones capuchinas en África. Vol I. Madrid: Instituto Santo Toribio de Mogrevejo. [2 vols.]

Anonymous, 1828. Marly, or, The Life of a Planter in Jamaica. Glasgow: R. Griffin.

Barcellos, Christiano José de Senna, 1899-1913. Subsídios para a história de Cabo Verde e Guiné. Vol I. Lisbon: Academia das Ciências de Lisboa. [7 vols.]

Barreto, João, 1938. História da Guiné, 1418-1918. Lisbon: Edição do autor.

Beckford, William, 179o. A Descriptive Account of the Island of Jamaica. Vol. I. London: T. and J. Egerton. [2 vols.]

Beirante, Maria Ângela, 199o. Confrarias medievais portuguesas. Lisbon: Maria Ângela Beirante.

Beirante, Maria Ângela, 2011. Territórios do sagrado: Crenças e comportamentos na Idade Média em Portugal. Lisbon: Colibri.

Belisario, I.M., 1837. Sketches of Character in Illustration of the Habits, Occupation and Costume of the Negro Population in the Island of Jamaica. Kingston: J.R. De Cordova. 
Bérenger-Féraud, Laurent-Jean-Baptiste, 1879. Les peuplades de la Sénégambie: Histoire, ethnographie, mours et coutumes, légendes, etc. Paris: E. Leroux.

Bethencourt, Francisco, 1998. A Igreja. In Francisco Bethencourt \& Kirti Chaudhuri (eds.), História da expansão portuguesa. Vol.v. Lisbon: Círculo de Leitores, pp. 36986. [5 vols.]

Bettelheim, Judith, 1979. Jamaican Jonkonnu and Related Caribbean Festivals. In Margaret E. Crahan \& Franklin W. Knight (eds.), Africa and the Caribbean: The Legacies of a Link. Baltimore MD: The Johns Hopkins University Press, pp. 80-100.

Bettelheim, Judith, 1985. The Lantern Festival in Senegambia. African Arts 18(2):50-54, 95-97, 101-2.

Bettelheim, Judith, 1988. Jonkonnu and other Christmas Masquerades. In John W. Nunley \& Judith Bettelheim (eds.), Caribbean Festival Arts: Each and Every Bit of Difference. Seattle: University of Washington Press, pp. 39-84.

Bilby, Kenneth, 2010. Surviving Secularization: Masking the Spirit in the Jankunu (John Canoe) Festivals of the Caribbean. New West Indian Guide 84(3/4):179-223.

Bolton, Henry Carrington, 189o. Gombay: A Festival Rite of Bermudian Negroes. Journal of American Folklore 3(10):222-26.

Borges, Célia Maia, 2005. Escravos e libertos nas irmandades do Rosário: Devoção e solidariedade em Minas Gerais, séculos XVIII e XIX. Juiz de Fora, Brazil: Editora UFJF.

Braga, Teófilo, 1885. O povo portuguez nos seus costumes, crenças e tradições. Vol. II. Lisbon: Ferreira. [2 vols.]

Brandão, Carlos Rodrigues, 1977. A folia de reis de Mossâmedes. Rio de Janeiro: Funarte.

Brásio, António (ed.), 1952-71. Monumenta missionária Africana. Vols II I and v. Lisbon: Agência Geral do Ultramar. [11 vols.]

Brásio, António (ed.), 1958-79. Monumenta missionária Africana: Segunda série. Vol. Iv. Lisbon: Agência Geral do Ultramar/Academia Portuguesa da História. [5 vols.]

Bratulescu, Monica, 1981. Colinda Românească: The Romanian Colinda. Bucharest: Editura Minerva.

Breen, Henry H., 1844. St. Lucia: Historical, Statistical, and Descriptive. London: Longman, Brown, Green \& Longmans.

Brenneker, Paul, 1969-75. Sambumbu:Volkskunde van Curaçao, Aruba en Bonaire. Vol. I. Curaçao: Drukkerij Scherpenheuvel. [10 vols.]

Brenneker, Paul, 1986. Zjozjoli: Gegevens over de volkskunde van Curaçao, Aruba en Bonaire. Curaçao: Publisidat Antiano.

Brewer-García, Larissa, 2020. Beyond Babel: Translations of Blackness in Colonial Peru and New Granada. Cambridge: Cambridge University Press.

Brooks, George E., 2003. Eurafricans in Western Africa: Commerce, Social Status, Gender, and Religious Observance from the Sixteenth to the Eighteenth Century. Athens: Ohio University Press. 
Burton, Richard D.E., 1997. Afro-Creole: Power, Opposition and Play in the Caribbean. Ithaca NY: Cornell University Press.

Campbell, Mavis, 1988. The Maroons of Jamaica 1655-1796: A History of Resistance, Collaboration \& Betrayal. Granby MA: Bergin \& Garvey.

Cañizares-Esguerra, Jorge, Matt D. Childs \& James Sidbury (eds.), 2013. The Black Urban Atlantic in the Age of the Slave Trade. Philadelphia: University of Pennsylvania Press.

Cascudo, Luís da Câmara, 1965. Antologia do folclore brasileiro. São Paulo: Martins Editora.

Chasteen, John Charles, 2004. National Rhythms, African Roots: The Deep History of Latin American Popular Dance. Albuquerque: University of New Mexico Press.

Chaves, Luís, 1945. Folclore religioso. Porto, Portugal: Portucalense.

Collymore, Frank A., 1957. Notes for a Glossary of Words and Phrases of Barbadian Dialect. Bridgetown: Advocate Co.

Cosentino, Donald J., 1995. It's all for You, Sen Jak! In Donald J. Cosentino (ed.), Sacred Arts of Haitian Vodou. Los Angeles: UCLA Fowler Museum of Cultural History, pp. 243-63.

Craton, Michael, 1995. Decoding Pitchy-Patchy: The Roots, Branches and Essence of Junkanoo. Slavery \& Abolition 16(1):14-44.

Crowley, Daniel J., 1958. La Rose and La Marguerite Societies in St. Lucia. The Journal of American Folklore 71(282):541-52.

Cruickshank, Brodie, 1853. Eighteen Years on the Gold Coast of Africa. London: Hurst and Blackett. [2 vols.]

Cundall, Frank (ed.), 1907. Lady Nugent's Journal, Jamaica One Hundred Years Ago. London: Institute of Jamaica, A. \& C. Black.

Curry, Robert A., 1978. Bahamian Lore. New York: Gordon Press. [Orig. 1928.]

Dawson, Kevin, 2019. Moros e Christianos [sic]: Ritualized Naval Battles, Baptizing American Waters with African Spiritual Meaning. In Cécile Fromont (ed.), AfroCatholic Festivals in the Americas: Performance, Representation, and the Making of Black Atlantic Tradition. University Park: The Pennsylvania State University Press, pp. $42-58$.

Debbasch, Yvan, 1959. Les associations serviles à la Martinique au Xıxe siècle. In Études d'histoire du droit privé offertes à Pierre Petot. Paris: Éditions Montchrestien, pp. 12130.

Dewar, Alfred, 1928. The Voyages and Travels of Captain Nathaniel Uring. London: Cassell and Company. [Orig. 1726.]

Dewulf, Jeroen, 2017. From the Kingdom of Kongo to Congo Square: Kongo Dances and the Origins of the Mardi Gras Indians. Lafayette: University of Louisiana at Lafayette Press.

Dirks, Robert, 1979. The Evolution of a Playful Ritual: The Garifuna's John Canoe in Comparative Perspective. In Edward Norbeck \& Claire R. Farrer (eds.), Forms of 
Play of Native North Americans. St. Paul MN: West Publishing Company, pp. 89110.

Dirks, Robert, 1987. The Black Saturnalia: Conflict and its Ritual Expression on British West Indian Slave Plantations. Gainesville: University Press of Florida.

Dumas, Alexandra Gouvêa, 2011. Maures et Chrétiens_-chemins, scènes, croyances et créations: Une analyse des spectacles de tradition carolingienne l'Auto de Floripes (l'île du Principe, São Tomé et Príncipe, Afrique) et la Lutte de Maures et Chrétiens (Prado, Bahia, Brésil). Ph.D. Dissertation, University Paris Ouest, Nanterre-La Defense.

Dunham, Katherine, 1946. Katherine Dunham's Journey to Accompong. New York: H. Holt and Company.

Edwards, Bryan, 1798. The History, Civil and Commercial, of the British Colonies in the West Indies. London: B. Crosby, Mundell \& Son, and J. Mundell.

Eekhof, Albert, 1917. De negerpredikant Jacobus Elisa Joannes Capitein, 1717-1747. The Hague: Martinus Nijhoff.

Felner, Alfredo de Albuquerque (ed.), 1933. Angola: Apontamentos sobre a ocupação e início do estabelecimento dos Portugueses no Congo, Angola e Benguela extraídos de documentos históricos. Coimbra, Portugal: Imprensa da Universidade.

Fonseca, Jorge, 2016. Religião e liberdade: Os Negros nas irmandades e confrarias portuguesas (séculos XV aXIX). V.N. Famalicão, Portugal: Humus.

Franco, António, 1726. Synopsis Annalium Societatis Jesu in Lusitania ab 1540 usque ad annum 1725. Augsburg, Germany: Sumptibus Philippi, Martini, \& Joannis Veith, Haeredum.

Friedman, Jonathan, 1997. Global Crises, the Struggle for Cultural Identity and Intellectual Porkbarrelling: Cosmopolitans versus Locals, Ethnics and Nationals in an Era of De-Hegemonisation. In Pnina Werbner \& Tariq Modood (eds.), Debating Cultural Hybridity: Multi-Cultural Identities and the Politics of Anti-Racism. London: Zed Books, pp. 70-9o.

Fromont, Cécile, 2014. The Art of Conversion: Christian Visual Culture in the Kingdom of Kongo. Chapel Hill: University of North Carolina Press.

Fromont, Cécile, 2019. Introduction. In Cécile Fromont (ed.), Afro-Catholic Festivals in the Americas: Performance, Representation, and the Making of Black Atlantic Tradition. University Park: The Pennsylvania State University Press, pp. 1-19.

García Martín, Judith Helvia, 2011. Música religiosa en la Castilla rural de los siglos XVIII yXIX. Salamanca, Spain: Ediciones Universidad Salamanca.

Guerra, Ramiro, 1989. Teatralización del folklore y otros ensayos. La Habana: Editorial Letras Cubanas.

Hair, P.E.H., 1978. Hamlet in an Afro-Portuguese Setting: New Perspectives on Sierra Leone in 1607. History in Africa 5:21-42.

Hair, P.E.H. (ed.), 1982. André de Faro's Missionary Journey to Sierra Leone in 1663-64. Freetown: Institute of African Studies, University of Sierra Leone. 
Handler, Jerome S. \& Charlotte J. Frisbie, 1972. Aspects of Slave Life in Barbados: Music and its Cultural Context. Caribbean Studies 11(4):5-46.

Harris, Max, 200o. Aztecs, Moors, and Christians: Festivals of Reconquest in Mexico and Spain. Austin: University of Texas Press.

Harris, Max, 2001. Masking the Site: The Fiestas de Santiago Apóstol in Loíza, Puerto Rico. The Journal of American Folklore 114(453):358-69.

Harris, Max, 20o6. Claiming Pagan Origins for Carnival: Bacchanalia, Saturnalia, and Kalends. European Medieval Drama 10:57-108.

Hartsinck, Jan Jacob, 1770. Beschryving van Guiana, of de Wilde Kust, in Zuid-America. Vol. II. Amsterdam: Gerrit Tielenburg. [2 vols.]

Havik, Philip J., 2004. Silences and Soundbites: The Gendered Dynamics of Trade and Brokerage in the Pre-Colonial Guinea Bissau Region. Münster, Germany: Lit Verlag.

Heywood, Linda \& John Thornton, 2007a. Central Africans, Atlantic Creoles, and the Foundation of the Americas, 1585-166o. New York: Cambridge University Press.

Heywood, Linda \& John Thornton, 2007b. Central-African Leadership and the Appropriation of European Culture. In Peter C. Mancall (ed.), The Atlantic World and Virginia, 1550-1624. Chapel Hill: University of North Carolina Press, pp. 194-224.

Higman, Barry (ed.), 1976. Characteristic Traits of the Creolian \& African Negroes in Jamaica (1797). Mona, Jamaica: Caldwell Press.

Hildebrand, P., 1940. Le martyr Georges de Geel et les débuts de la mission au Congo, 16451652. Antwerp, Belgium: Archives des Capucins.

Hurston, Zora Neale, 199o. Tell My Horse: Voodoo and Life in Haiti and Jamaica. New York: Harpers \& Row. [Orig. 1938.]

Jadin, Louis (ed.), 1961. Le Congo et la secte des Antoniens: Restauration du Royaume sous Pedro IV et la "Saint Antoine" congolaise (1694-1718). Bulletin de l'Institut Historique Belge de Rome 32:411-614.

King, John, 1822. Extraits de relation inédite d' un voyage fait, en 1820, aux royaumes de Benin et de Warree. In J.-T. Verneur (ed.), Journal des Voyages, Vol. XIII. Paris: Colnet, Roret et Roussel, Arthus Bertrand, pp. 313-18. [44 vols.]

Kohl, Christoph, 2018. A Creole Nation: National Integration in Guinea-Bissau. New York: Berghahn.

Lahon, Didier, 2001. Esclavage et confréries noires au Portugal durant l' Ancien Régime (1441-1830). Ph.D. Dissertation, École des Hautes Études en Sciences Sociales, Paris.

Laing, Annette, 2002. "Heathens and Infidels"? African Christianization and Anglicanism in the South Carolina Low Country, 1700-1750. Religion and American Culture 12(2):197-228.

Le Gentil de La Barbinais, Étienne M., 1728. Nouveau voyage autour du monde. Vol. III. Amsterdam: P. Mortier. [3 vols.]

Leigh, Devin, 2019. The Jamaican Airs: An Introduction to Unpublished Pieces of Musical Notation from Enslaved People in the Eighteenth-Century Caribbean. Atlantic Studies 17(4):462-84. 
Lewis, Matthew Gregory, 1834. Journal of a West-India Proprietor, Kept During a Residence in the Island of Jamaica. London: J. Murray.

Lima, Rossini Tavares de, 1962. Folguedos populares do Brasil. São Paulo: Ricordi.

Liscano, Juan, 199o. Fuegos sagrados. Caracas: Monte Ávila Editores.

Long, Edward, 1774. The History of Jamaica or, General Survey of the Antient and Modern State of the Island. Vol. II. London: T. Lowndes. [3 vols.]

Marees, Pieter De, 1912. Beschryvinghe ende historische verhael van het Gout koninkrijck van Gunea anders de Gout-Custe de Mina genaemt liggende in het deelvan Africa, ed. S.P. L'Honoré Naber. The Hague: Martinus Nijhoff. [Orig. 16o2.]

Marques, A.H. de Oliveira, 1971. Daily Life in Portugal in the Late Middle Ages, trans. S.S. Wyatt. Madison: University of Wisconsin Press.

Martinez-Ruiz, Barbaro, 2007. Sketches of Memory: Visual Encounters with Africa in Jamaican Culture. In Tim Barringer, Gillian Forrester \& Barbaro Martinez-Ruiz (eds.), Art and Emancipation in Jamaica: Isaac Mendes Belisario and His World. New Haven CT: Yale University Press, pp. 103-19.

Mauldin, Barbara, 1999. Masks of Mexico: Tigers, Devils, and the Dance of Life. Santa Fé: Museum of New Mexico Press.

Meintel, Deirdre, 1984. Race, Culture, and Portuguese Colonialism in Cabo Verde. Syracuse NY: Syracuse University Press.

Meredith, Sharon, 2015. Tuk Music Tradition in Barbados. Farnham, U.K.: Ashgate.

Miller, Joseph C., 2002. Central Africans during the Era of the Slave Trade, c. 149os185os. In Linda Heywood (ed.), Central Africans and Cultural Transformation in America. Cambridge: Cambridge University Press, pp. 21-69.

Mintz, Sidney \& Richard Price, 1992. The Birth of African-American Culture: An Anthropological Perspective. Boston: Beacon Press.

Monteiro, Félix, 1948-49. Tabanca. Claridade: Revista de Arte e Letras 6 (July 1948):14-18 and 7 (December 1949):19-26.

Morales Padrón, Francisco, 2003. Spanish Jamaica, trans. Patrick E. Bryan. Kingston: Ian Randle.

Moreno, Isidoro, 1997. La antigua Hermandad de Los Negros de Sevilla: Etnicidad, poder y sociedad en 6 oo años de historia. Sevilla, Spain: Universidad de Sevilla.

Müller, Wilhelm Johann, 1968. Die Afrikanische auf der Guineischen Gold-Cust gelegene Landschaft Fetu. Graz, Austria: Akademische Druck- \& Verlagsanstalt. [Orig. 1672.]

Mufwene, Salikoko S., 1996. The Founder Principle in Creole Genesis. Diacronica 13(1): 83-134.

Mullin, Michael, 1992. Africa in America: Slave Acculturation and Resistance in the American South and the British Caribbean, 1736-1831. Urbana: University of Illinois Press.

Nicholls, Robert Wyndham, 2012. The Jumbies' Playing Ground: Old World Influences on Afro-Creole Masquerades in the Eastern Caribbean. Jackson: University Press of Mississippi. 
Obeng, Pashington, 1996. Asante Catholicism: Religious and Cultural Reproduction among the Akan of Ghana. Leiden, the Netherlands: Brill.

Oldendorp, Christian Georg Andreas, 200o. Historie der caribischen Inseln Sanct Thomas, Sanct Crux und Sanct Jan, insbesondere der dasigen Neger und der Mission der evangelischen Brüder unter denselben, eds. Gudrun Meier, Stephan Palmié, Peter Stein \& Horst Ulbricht. Vols I and II. Berlin: VWB. [2 vols.]

Oliveira, Ernesto Veiga de, 1984. Festividades cíclicas em Portugal. Lisbon: Dom Quixote.

Oudschans Dentz, Frederik, 1920. De beteekenis van "Jan Compon." Nederlandsch Archief voor Kerkgeschiedenis (Januari 1):89-94.

Panhuys, L.C. van, 1933/34. Folklore van Bonaire. De West-Indische Gids 16:318-20.

Peabody, Sue, 2002. A Dangerous Zeal: Catholic Missions to Slaves in the French Antilles, 1635-180o. French Historical Studies 25(1):53-9o.

Pereira, Daniel A., 2005. Estudos da história de Cabo Verde. Praia: Alfa-Comunicações.

Pereira, Isaías da Rosa, 1968. Dois compromissos de irmandades de homens pretos. Arqueologia e Historia 9(4):9-47.

Pestana, Carla Gardina, 2017. The English Conquest of Jamaica: Oliver Cromwell's Bid for Empire. Cambridge MA: Harvard University Press.

Phillippo, James M., 1843. Jamaica: Its Past and Present State. Philadelphia PA: J.M. Campbell.

Phillips Jr., William D., 2014. Slavery in Medieval and Early Modern Iberia. Philadelphia: University of Pennsylvania Press.

Rawlings, Helen, 2002. Church, Religion and Society in Early Modern Spain. New York: Palgrave.

Reade, William Winwood, 1864. Savage Africa: Being the Narrative of a Tour in Equatorial, Southwestern and Northwestern Africa. New York: Harper \& Brothers.

Reis, Fernando, 1969, Pôvô flogá: Folclore de São Tomé e Príncipe. São Tomé: Câmara Municipal.

Rosalia, René V., 1997. Tambú: De legale en kerkelijke repressie van Afro-Curaçaose volksuitingen. Zutphen, the Netherlands: Walburg Pers.

Roussier, Paul, 1935. L'Établissement d'Issiny, 1687-1702: Voyages de Ducasse, Tibierge et d'Amon à la Côte de Guinée publiés pour la première fois et suivis de la Relation du voyage du Royaume d'Issiny du P. Godefroy Loyer. Paris: Larose.

Rowe, Erin Kathleen, 2019. Black Saints in Early Modern Global Catholicism. Cambridge: Cambridge University Press.

Ruiz, Teofilo R., 2012. A King Travels: Festive Traditions in Late Medieval and Early Modern Spain. Princeton NJ: Princeton University Press.

Schuler, Monica, 1979. Myalism and the African Religious Tradition in Jamaica. In Margaret E. Crahan \& Franklin W. Knight (eds.), Africa and the Caribbean: The Legacies of a Link. Baltimore MD: The Johns Hopkins University Press, pp. 65-79.

Scott, Michael, 1835. Tom Cringle's Log. New York: Wallis \& Newell. 
Sensbach, Jon F., 2005. Rebecca's Revival: Creating Black Christianity in the Atlantic World. Cambridge MA: Harvard University Press.

Sierra Silva, Pablo Miguel, 2020. Afro-Mexican Women in Saint-Domingue: Piracy, Captivity, and Community in the 168 os and 169os. Hispanic American Historical Review $100(1): 3-34$.

Sloane, Hans, 1707. A Voyage to the Islands Madera, Barbados, Nieves, S. Christophers and Jamaica. Vol. I. London: printed by B.M. for the author. [2 vols.]

Souza, Marina de Mello e, 2005. Reis do Congo no Brasil. Séculos XVIII e XIX. Revista de História 152(1):79-98.

Souza, Marina de Mello e, 2015. Kongo King Festivals in Brazil: From Kings of Nations to Kings of Kongo. African Studies Quarterly 15(3):39-45.

Stewart, Dianne M., 2019. The Orisha House That Afro-Catholics Built: Africana Antecedents to Yoruba Religious Formation in Trinidad. In Cécile Fromont (ed.), AfroCatholic Festivals in the Americas: Performance, Representation, and the Making of Black Atlantic Tradition. University Park: The Pennsylvania State University Press, pp. 140-6o.

Terreros y Pando, Esteban de. 1786-93. Diccionario castellano con las voces de ciencias $y$ artes y sus correspondientes en las tres lenguas francesa, latina e italiana. Vol. I. Madrid: Viuda de Ibarra. [4 vols.]

Thompson, Robert Farris, 2007. Charters for the Spirit: Afro-Jamaican Music and Art. In Tim Barringer, Gillian Forrester \& Barbaro Martinez-Ruiz (eds.), Art and Emancipation in Jamaica:Isaac Mendes Belisario and His World. New Haven CT:Yale University Press, pp. 89-101.

Thornton, John, 1984. The Development of an African Catholic Church in the Kingdom of Kongo, 1491-1750. The Journal of African History 25(2):147-67.

Thornton, John, 1998. The Kongo Saint Anthony: Dona Beatriz Kimpa Vita and the Antonian Movement, 1684-1706. Cambridge: Cambridge University Press.

Thornton, John, 2007. Portuguese-African Relations, 1500-1750. In Jay A. Levenson (ed.), Encompassing the Globe: Portugal and the World in the Sixteenth and Seventeenth Centuries. Washington DC: Smithsonian Institution, pp. 57-63.

Torres, Marilu, 2014. Brasil: Terra de todos os santos. São Paulo: Panda Books.

Trajano Filho, Wilson, 20og. Os cortejos das tabancas: Dois modelos da ordem. In Maria Laura Viveiros de Castro Cavalcanti \& José Reginaldo Santos Gonçalves (eds.), As festas e os dias: Ritos e sociabilidades festivas. Rio de Janeiro: Contra Capa, pp. 37-73.

Turner, Mary, 1982. Slaves and Missionaries: The Disintegration of Jamaican Slave Society, 1787-1834. Urbana: University of Illinois Press.

Valverde, Paulo, 1998. Carlos Magno e as artes da morte: Estudo sobre o Tchiloli da Ilha de São Tomé. Etnográfica 2:221-50.

Vasconcellos, Carolina Michaelis de, 1904. Cancioneiro da Ajuda, edição crítica e commentada. Vol. II. Halle, Germany: Max Niemeyer. [2 vols.] 
Vilar, Hermínia Vasconcelos, 1995. A vivência da morte no Portugal medieval: A Estremadura portuguesa (1300 a 1500). Redondo, Portugal: Patrimónia.

Vincent, Bernard, 200o. Les confréries de noirs dans la Péninsule Ibérique (XV-XVIII siècles). In David González Cruz (ed.), Religiosidad y costumbres populares en Iberoamérica. Huelva, Spain: Universidad de Huelva, pp. 17-28.

Warner-Lewis, Maureen, 2003. Central Africa in the Caribbean: Transcending Time, Transforming Cultures. Kingston: University of West Indies Press.

Warren, Edward, 1885. A Doctor's Experiences in Three Continents. Baltimore MD: Cushings \& Bailey.

Weed, Thurlow, 1866. Letters from Europe and the West Indies, 1843-1862. Albany NY: Weed, Parsons and Company.

Wheat, David, 2016. Atlantic Africa and the Spanish Caribbean, 1570-1640. Chapel Hill: University of North Carolina Press.

Williams, Cynric R., 1826. A Tour through the Island of Jamaica: From the Western to the Eastern End, in the Year 1823. London: Hunt and Clarke.

Wiltgen, Ralph M., 1956. Gold Coast Mission History, 1471-1880. Techny IL: Divine Word Publications.

Wright, Richardson Little, 1937. Revels in Jamaica, 1682-1832. New York: Dodd. 